ISSN = 1980-993X - doi:10.4136/1980-993X
www.ambi-agua.net
E-mail: ambi-agua@agro.unitau.br
Tel.: (12) 3631-8004

\title{
Watershed services payments to smallholders in the Brazilian Amazon: challenges and perspectives
}

\author{
doi: 10.4136/ambi-agua.1056
}

\author{
Ricardo de O. Figueiredo ${ }^{1 *}$, Jan Börner ${ }^{2}$, and Eric A. Davidson ${ }^{3}$ \\ ${ }^{1}$ EMBRAPA Meio Ambiente- Jaguariúna, SP, Brasil \\ ${ }^{2}$ University of Bonn - Bonn, Germany \\ Center for Development Research (ZEF) \\ ${ }^{3}$ The Woods Hole Research Center - Falmouth, MA, USA \\ *Autor correspondente: e-mail: ricardo.figueiredo@embrapa.br, \\ jborner@uni-bonn.de,edavidson@whrc.org
}

\begin{abstract}
Several hydrobiogeochemical research activities have been conducted in the Eastern Amazon, contributing to the understanding of how changes in forests and agro-ecosystems affect the provision of services to ecosystems. The findings have demonstrated that good agricultural practices and the presence of natural secondary vegetation favored by the management of small family farms are important factors for hydrobiogeochemical cycling, aquatic ecosystem conservation, soil conservation, and mitigation of trace gases emissions from biomass burning in Amazonian small catchments. Two challenges for watershed service management arise in this context. First, low population densities and the relatively flat landscape mean that a critical mass of downstream beneficiaries of such services - a prerequisite for public intervention is more difficult to identify than in more densely populated mountainous areas. Second, although watershed service providers (farmers) are also to a considerable extent service beneficiaries, conflicts over land and cultural heterogeneities among settlers inhibit local collective action to safeguard the quality of stream water. Including small landholders in carbon payment schemes that compensate for the maintenance of riverbank vegetation would appear to be a cost-effective means to secure watershed services as additional benefits of forest-based mitigation of climate change.
\end{abstract}

Keywords: Stream water quality, hydrobiogeochemistry, good agricultural practices, watershed management, payments for ecosystem services.

\section{Pagamento por serviços hídricos a agricultores familiares na Amazônia oriental: desafios e perspectivas}

\section{RESUMO}

Diversos estudos hidrobiogeoquímicos têm sido realizados na Amazônia oriental para contribuir no entendimento sobre como as mudanças em ecossistemas florestais e agroecossistemas afetam a provisão de serviços ecossistêmicos. Os seus resultados demonstram que as boas práticas agrícolas e a presença da vegetação secundária favorecidas pelo manejo agrícola na agricultura familiar são fatores importantes para a ciclagem hidrobiogeoquímica, a conservação do ecossistema aquático, a conservação dos solos e a mitigação das emissões de gases traço oriundos da queima de biomassa em pequenas bacias amazônicas. Neste contexto dois desafios se apresentam para a gestão dos serviços hídricos. Primeiramente observa-se que a baixa densidade populacional e o relevo relativamente plano resultam que uma massa crítica de beneficiários a jusante de tais serviços - um prerequisito para a intervenção pública - torna-se de mais difícil sua identificação do que em áreas 
FIGUEIREDO, R. O.; BÖRNER, J.; DAVIDSON, E. A. Watershed services payments to smallholders in the Brazilian Amazon: challenges and perspectives Ambi-Agua, Taubaté, v. 8, n. 2, p. 6-17, 2013. (http://dx.doi.org/10.4136/ambi-agua.1056)

montanhosas mais densamente povoadas. Em segundo lugar, os provedores de serviços hídricos (produtores rurais) sejam em certa medida também beneficiários, os conflitos de terra e a heterogenidade cultural entre eles inibe uma ação coletiva local para salvaguardar a qualidade da água. A inclusão de agricultores familiares em arranjos para pagamento por carbono que compensem a manutenção da vegetação ripária parece ser uma solução financeira efetiva para assegurar os serviços hídricos como benefícios adicionais na mitigação das mudanças climáticas com base na conservação de florestas.

Palavras-chave: Qualidade de água fluvial, hydrobiogeoquímica, boas práticas agrícolas, manejo de bacia, pagamento por serviços ecossistêmicos.

\section{INTRODUCTION}

Agricultural frontiers in the Brazilian Amazonia are expanding into the forest, compromising terrestrial and aquatic ecosystem structure and function, including fluxes of nutrients, carbon and water in small catchments (Tomasella et al., 2009). These first and second order streams comprise $80 \%$ of the total riverine habitat throughout this region (McClain and Elsenbeer, 2001). Several hydrobiogeochemical research activities have been conducted in the Eastern Amazon, contributing to the understanding of how changes in forests and agro-ecosystems affect ecosystem service provision.

In addition to carbon storage and biodiversity maintenance, water cycling is an important environmental service provided by the conservation of the Amazonian forests. The magnitude and value of these services are poorly quantified (Fearnside, 2005). Among other urgent policy actions, it has been suggested that family agriculture should be fortified rather than the current policy focus on promoting large landholders (Fearnside, 2001). In this sense, among other measures, it is suggested that consideration should be given to the possibility of payments for environmental services as a source of support.

In the Eastern Amazon in Brazil, the use of fire for land preparation is still a widespread practice in many traditional agricultural systems. Reducing the use of fire could be an important step towards sustainable agriculture for small land holders. Conservative practices, such as mulching in combination with zero tillage, have shown promising results in experiments (Sommer, 2001). Innovative policy programs, such as payments for environmental services, could help to promote the introduction of this and other alternatives to slash-and-burn agriculture by compensating farmers for additional watershed services, including forest conservation. Bennett et al. (2013) provide an accurate snapshot of the scale, size, shape, and direction of investments in watershed services worldwide. However, the development of payments for watershed services schemes currently hinges on a better understanding of the biophysical determinants of hydrological service provision, especially in the Amazon region.

In the present manuscript we review research on hydrobiogeochemistry of Amazonian agro-ecosystems in small land holder and large-scale producer managed watersheds. Given the clear link between agricultural practices and stream water quality, we discuss the potential role of payments for watershed services plans in the regional context.

\section{HYDROBIOGEOCHEMICAL ASPECTS}

Large scale agriculture, such as cattle ranching and row crops, tends to radically change the natural characteristics of small rivers and streams, whereas small landholder agriculture, characterized by secondary forest mosaic landscapes, has a less disturbing effect on small rivers and streams, especially when slash-and-burn land preparation practices are avoided. Research has demonstrated that good agricultural practices and the presence of natural 
FIGUEIREDO, R. O.; BÖRNER, J.; DAVIDSON, E. A. Watershed services payments to smallholders in the Brazilian Amazon: challenges and perspectives Ambi-Agua, Taubaté, v. 8, n. 2, p. 6-17, 2013. (http://dx.doi.org/10.4136/ambi-agua.1056)

secondary vegetation favored by small landholder farm management are important factors for hydrobiogeochemical cycling, aquatic ecosystem conservation, soil conservation, and mitigation of trace gas emissions from biomass burning in small Amazonian catchments (Davidson et al., 2008). In Table 1, we present a calculation for two different systems in eastern Amazonia which shows that the GWP (Greenhouse Warming Potential) $\mathrm{CO}_{2}$ (dioxide carbon) equivalents from soil emissions, fertilizer use, and diesel fuel use in the chop-andmulch system were not trivial, but they were nearly six times smaller than the total GWP $\mathrm{CO}_{2}$ equivalents of slash-and-burn system extensively used by small landholder farming in the region

Other biogeochemical catchment studies more specifically related to water resources have shown pasture stream channels were deeper and had a lower cover of sandy bottom habitat and a higher cover of aquatic grass habitat than the forest streams, as well as lower concentrations of dissolved oxygen and nitrate $\left(\mathrm{NO}_{3}{ }^{-}\right)$and higher concentrations of dissolved iron $\left(\mathrm{Fe}^{2+}\right)$ and phosphate $\left(\mathrm{PO}_{4}^{3-}\right)$ (Neill et al., 2006). The stream chemistry of these two pairs of forest and pasture watersheds are compared in Table 2.

Table 1. Comparison of greenhouse warming potentials (GWP) for a 100-year time frame of emissions from slash-and-burn and chop-and-mulch cropping systems over approximately a 2year cycle.

\begin{tabular}{l|c|c|c|c}
\hline & \multicolumn{2}{|c|}{ Slash-and-burn } & \multicolumn{2}{c}{ Chop-and-mulch } \\
\cline { 2 - 5 } & Flux & $\mathrm{CO}_{2}$ equivalents & Flux & $\mathrm{CO}_{2}$ equivalents \\
\hline Soil $\mathrm{CH}_{4}$ efflux & -5.0 & 120 & 16 & 370 \\
Fire $\mathrm{CH}_{4}$ emissions & 630 & 14000 & 0 & 0 \\
Soil $\mathrm{N}_{2} \mathrm{O}-\mathrm{N}$ efflux & 2.9 & 1300 & 4.2 & 2000 \\
Fire $\mathrm{N}_{2} \mathrm{O}-\mathrm{N}$ emissions & 12 & 5600 & 0 & 0 \\
$\mathrm{~N}$ fertilizer & 0 & 0 & 90 & 370 \\
P fertilizer & 0 & 0 & 60 & 37 \\
K fertilizer & 0 & 0 & 30 & 13 \\
Diesel fuel for mulching & 0 & 0 & 300 & 780 \\
\hline Total CO equivalents & & 21000 & & 3600 \\
\hline
\end{tabular}

Note: All values are in $\mathrm{kg} \mathrm{ha}^{-1}$, except for diesel fuel, which is in $\mathrm{L} \mathrm{ha}^{-1}$. All values are rounded to two significant figures. $\mathrm{CH}_{4}$, methane; $\mathrm{N}_{2} \mathrm{O}$, nitrous oxide; $\mathrm{N}$, nitrogen; $\mathrm{P}$, phosphorus; $\mathrm{K}$, potassium.

Source: Davidson et al. (2008).

In a related article, the authors suggest that some links among deforestation, soil biogeochemistry and the amount of nitrogen $(\mathrm{N})$ and phosphorus $(\mathrm{P})$ reaching small streams have the potential to influence the structure of these aquatic ecosystems (Neill et al., 2001). The authors point out that lower ratios of inorganic and total dissolved N:P in pasture streams suggest a switch from $\mathrm{P}$ limitation in forest streams to $\mathrm{N}$ limitation in pasture streams. In addition, periphyton bioassays in these forest and pasture streams confirmed that $\mathrm{N}$ limited algal growth in pasture streams where light was available. Figure 1 serves as an illustration of the dimension and environmental aspects of the studied streams. 
FIGUEIREDO, R. O.; BÖRNER, J.; DAVIDSON, E. A. Watershed services payments to smallholders in the Brazilian Amazon: challenges and perspectives Ambi-Agua, Taubaté, v. 8, n. 2, p. 6-17, 2013. (http://dx.doi.org/10.4136/ambi-agua.1056)

Table 2. Nutrient, cation and total suspended sediment concentrations in forest and pasture streams at Nova Vida Ranch, Rondônia, Brazil, during the period of low flows in August to September of 1998 and 1999. Different superscripts indicate that forest and pasture means within each stream pair were significantly different (t-test, $\mathrm{p}<0.05$ ).

\begin{tabular}{l|c|cc|cc}
\hline \multirow{2}{*}{ Parameters } & \multirow{2}{*}{ Units } & \multicolumn{2}{c|}{ Watershed 1 } & \multicolumn{2}{c}{ Watershed 2 } \\
\cline { 3 - 6 } & & Forest & Pasture & Forest & Pasture \\
\hline Dissolved Oxygen & $\mathrm{mg} \mathrm{L} \mathrm{L}^{-1}$ & $6.9^{\mathrm{a}}$ & $0.1^{\mathrm{b}}$ & $6.7^{\mathrm{a}}$ & $0.1^{\mathrm{b}}$ \\
$\mathrm{NO}_{3}{ }^{-}$ & $\mu \mathrm{M}$ & $10.7^{\mathrm{a}}$ & $6.5^{\mathrm{b}}$ & $8.1^{\mathrm{a}}$ & $3.5^{\mathrm{b}}$ \\
$\mathrm{NH}_{4}{ }^{3-}$ & $\mu \mathrm{M}$ & $4.5^{\mathrm{a}}$ & $6.9^{\mathrm{a}}$ & $4.9^{\mathrm{a}}$ & $4.0^{\mathrm{a}}$ \\
$\mathrm{PO}_{4}{ }^{3-}$ & $\mu \mathrm{M}$ & $0.2^{\mathrm{a}}$ & $1.8^{\mathrm{b}}$ & $0.5^{\mathrm{a}}$ & $0.8^{\mathrm{a}}$ \\
$\mathrm{DIN}^{2}$ DIP & & 76 & 7 & 26 & 9 \\
$\mathrm{Ca}^{2+}$ & $\mu \mathrm{M}$ & $87^{\mathrm{a}}$ & $104^{\mathrm{a}}$ & $112^{\mathrm{a}}$ & $110^{\mathrm{a}}$ \\
$\mathrm{Mg}^{2+}$ & $\mu \mathrm{M}$ & $79^{\mathrm{a}}$ & $95^{\mathrm{a}}$ & $123^{\mathrm{a}}$ & $109^{\mathrm{a}}$ \\
$\mathrm{K}^{+}$ & $\mu \mathrm{M}$ & $84^{\mathrm{a}}$ & $189^{\mathrm{b}}$ & $64^{\mathrm{a}}$ & $209^{\mathrm{b}}$ \\
$\mathrm{Na}^{+}$ & $\mu \mathrm{M}$ & $63^{\mathrm{a}}$ & $85^{\mathrm{b}}$ & $67^{\mathrm{a}}$ & $104^{\mathrm{b}}$ \\
$\mathrm{Fe}^{2+}$ & $\mu \mathrm{M}$ & $19^{\mathrm{a}}$ & $956^{\mathrm{b}}$ & $15^{\mathrm{a}}$ & $441^{\mathrm{b}}$ \\
$\mathrm{Total}^{2+}$ suspended sediments & $\mathrm{mg} \mathrm{L}$ & $11.4^{\mathrm{a}}$ & $13.5^{\mathrm{a}}$ & $6.0^{\mathrm{a}}$ & $19.2^{\mathrm{b}}$ \\
\hline
\end{tabular}

Source: Neill et al. (2006).

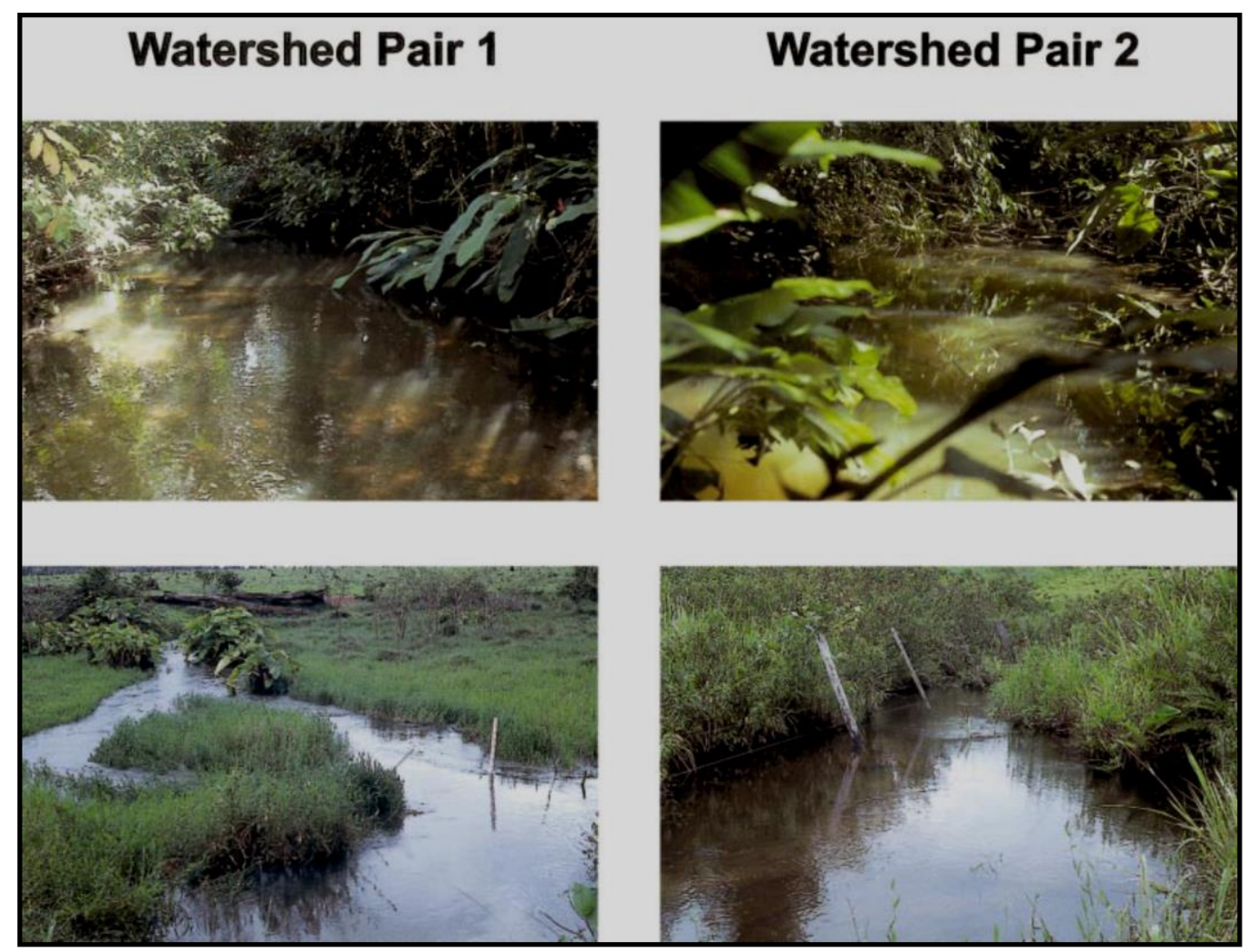

Figure 1. Photos of (top) forest and (bottom) pasture studied streams.

Source: Neill et al. (2001)

Whereas the overland flow production is negligible in Amazon forests, overland flow represents a significant pathway for additional loss of phosphorus and other elements from pastures to the streams (Biggs et al., 2006). A photograph (Figure 2) of a pasture hill slope in this study area illustrates the importance of this component of the hydrological cycle in the 
FIGUEIREDO, R. O.; BÖRNER, J.; DAVIDSON, E. A. Watershed services payments to smallholders in the Brazilian Amazon: challenges and perspectives Ambi-Agua, Taubaté, v. 8, n. 2, p. 6-17, 2013. (http://dx.doi.org/10.4136/ambi-agua.1056)

catchment, where we can see the cattle trail conveying the water of the overland flow. In the same region another study testing the effects of the landscape characteristics on river water chemistry, performed a multiple linear regression analysis and estimated a threefold increase of phosphate concentration in stream water due to an increase of $10 \%$ in the pasture area of a river basin (Ballester et al., 2003).

Identifying the sources and mechanisms of solute contribution to Amazonian streams is necessary for understanding nutrient cycling processes in mature tropical forests and the longterm effects of land use change in the region. Regarding this objective, a particular watershed where the soil was previously enriched in cations by forest clearing and burning 30 years previously showed an increase in the leaching of cations during the wet season which in turn increased the input of these elements into the streams (Markewitz et al., 2001).

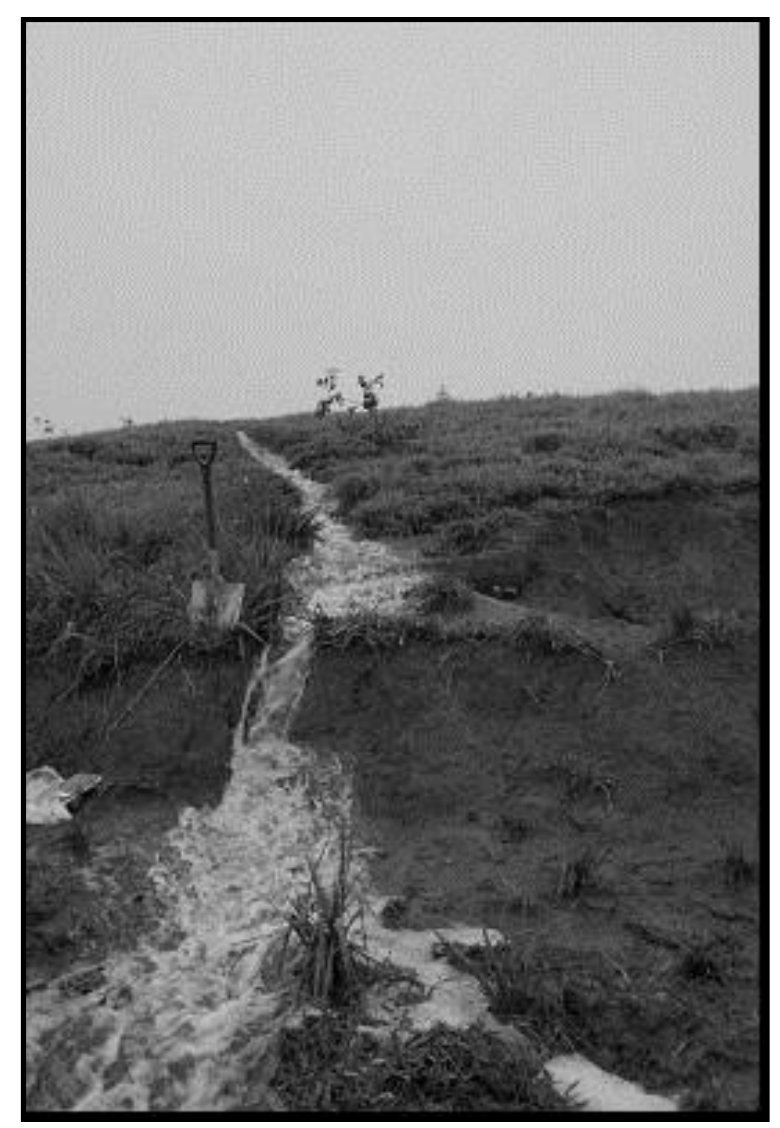

Figure 2. Photograph of a pasture hill slope as viewed from the overland flow sampling location, with runoff at the end of an $11-\mathrm{mm}$ rainstorm. In the photo we can see the cattle trail conveying the water.

Source: Biggs et al. (2006).

In contrast to pasture streams, where crops were grown near the stream, increases in steam concentrations of nitrate, sodium, chloride, and turbidity have been observed to increase with increasing crop cover area (Figueiredo et al., 2010). In this evaluation, land use change affected water chemistry and other measures of stream water quality in eastern Amazon catchments. Box plot graphs in Figure 3 illustrate upstream-downstream trends for $\mathrm{pH}$, nitrate (as $\mathrm{Ln} \mathrm{NO}_{3}{ }^{-} \mathrm{N}$ ), and dissolved oxygen (DO) in three streams (IG54, IG7 and IGP). Upstream-downstream trends in $\mathrm{pH}$ are decreasing for IG54 while $\mathrm{pH}$ increases downstream in IG7 and IGP, which can be attributed to impacts in the headwaters of IG54. On the other 
FIGUEIREDO, R. O.; BÖRNER, J.; DAVIDSON, E. A. Watershed services payments to smallholders in the Brazilian Amazon: challenges and perspectives Ambi-Agua, Taubaté, v. 8, n. 2, p. 6-17, 2013. (http://dx.doi.org/10.4136/ambi-agua.1056)

hand, nitrate upstream-downstream declines were associated with a decreasing in the percentage of forest area, while agricultural inputs are suspected of causing the observed nitrate spike and dissolved oxygen collapse in station 4 of the IG54.
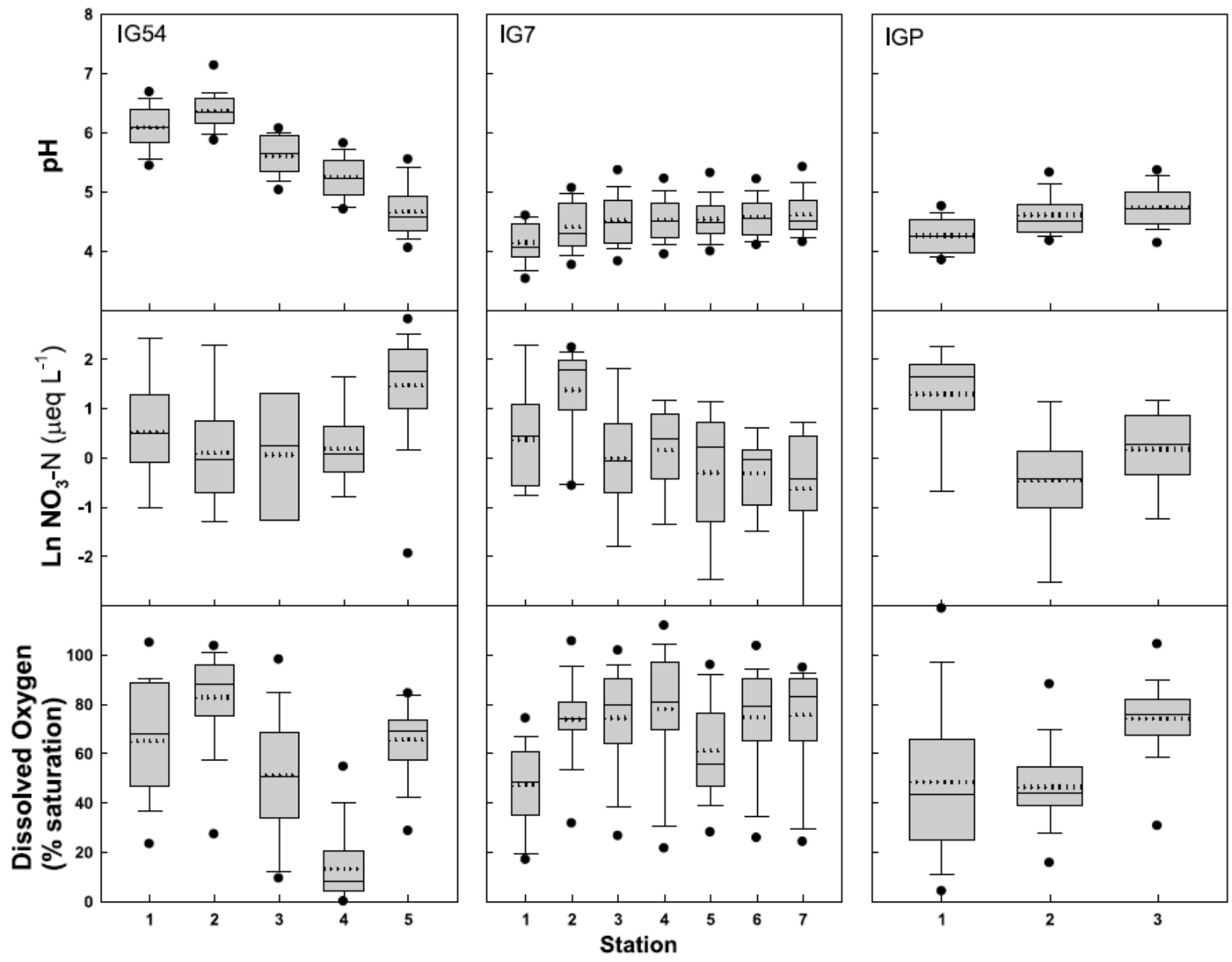

Figure 3. Upstream-downstream trends for $\mathrm{pH}$, nitrate $\left(\mathrm{Ln} \mathrm{NO}_{3}{ }^{-}-\mathrm{N}\right)$, and dissolved oxygen (DO) in three streams of eastern Amazonia (IG54, IG7, and IGP). Lower and upper boundaries of the box are the 25th and 75th percentile, dots are the 5th and 95th, the solid line is the median, and the dotted line is the mean for samples that were collected monthly from April 2003 to October 2005.

Source: Figueiredo et al. (2010).

The benefits of small landholder production systems in term of watershed services are strongly related to the amount of secondary forests available in the landscape. Secondary forests may become increasingly important as moderators of hydrologic cycles in the Amazon Basin as agricultural lands are abandoned and often later cleared again for agriculture (Vieira et al., 2003). In catchments primarily occupied by small landholders, large areas of secondary forest, together with good agriculture practices that avoid slash-and-burn land preparation, resulted in the conservation of almost natural stream characteristics (Figueiredo, 2009).

In a watershed study (drainage areas < 30 ha), in the eastern Amazonia, it was observed that, in a catchment where fire was used to prepare land for the planting of small crops or pasture renovation showed additional nutrient losses from soils to streamwater when compared to a catchment mainly occupied by secondary forests or chop-and-mulching to agriculture management (Wickel, 2004). In Table 3, we observe the mean chemical composition of base flow stream water of these two different types of watersheds according to 
FIGUEIREDO, R. O.; BÖRNER, J.; DAVIDSON, E. A. Watershed services payments to smallholders in the Brazilian Amazon: challenges and perspectives Ambi-Agua, Taubaté, v. 8, n. 2, p. 6-17, 2013. (http://dx.doi.org/10.4136/ambi-agua.1056)

land preparation and ratio of concentrations in base flow to the concentrations in rain. This approach demonstrates larger losses of potassium, calcium, magnesium, sulfate, and nitrate from slash-and-burn agriculture watershed soils compared to chop-and-mulching watershed soils losses to stream water.

Table 3. Mean chemical composition (in $\mathrm{mg} \mathrm{L}^{-1}$ ) of base flow water of two watersheds, and ratio of concentrations in base flow to the concentration in rain $(\mathrm{Q} / \mathrm{P}$ ratio). WS1 $=25.5$ ha chop-and-mulching agriculture watershed; WS2 $=28.6$ ha slash-and-burn agriculture watershed.

\begin{tabular}{l|cccccccc}
\hline Watersheds & $\mathbf{N a}^{+}$ & $\mathbf{K}^{+}$ & $\mathbf{C a}^{2+}$ & $\mathbf{M g}^{2+}$ & $\mathbf{S O}_{4}{ }^{2-}$ & $\mathbf{P O}_{4}{ }^{3-}$ & $\mathbf{N O}^{-}$ & $\mathbf{C l}^{-}$ \\
\hline WS 1 & & & & & & & & \\
Mean & 1.45 & 0.09 & 0.16 & 0.20 & 0.41 & 0.03 & 0.02 & 2.63 \\
WS1/Rain & 2.37 & 0.56 & 1.31 & 3.34 & 2.32 & 0.75 & 1.74 & 2.51 \\
\hline WS 2 & & & & & & & & \\
Mean & 1.40 & 0.20 & 0.61 & 0.29 & 0.81 & 0.02 & 0.04 & 2.58 \\
WS2/Rain & 2.30 & 1.21 & 4.99 & 4.83 & 4.65 & 0.57 & 4.47 & 2.46 \\
\hline
\end{tabular}

Source: Modified from Wickel (2004).

Another study in the eastern Amazonia that analyzed stream water chemistry in nine watersheds also measured larger catchment output of calcium related to fire in agriculture fields (Barroso, 2011). In Figure 4, we can see larger concentrations due to slash-and-burn agriculture in the M4, M5 and M6 watersheds.

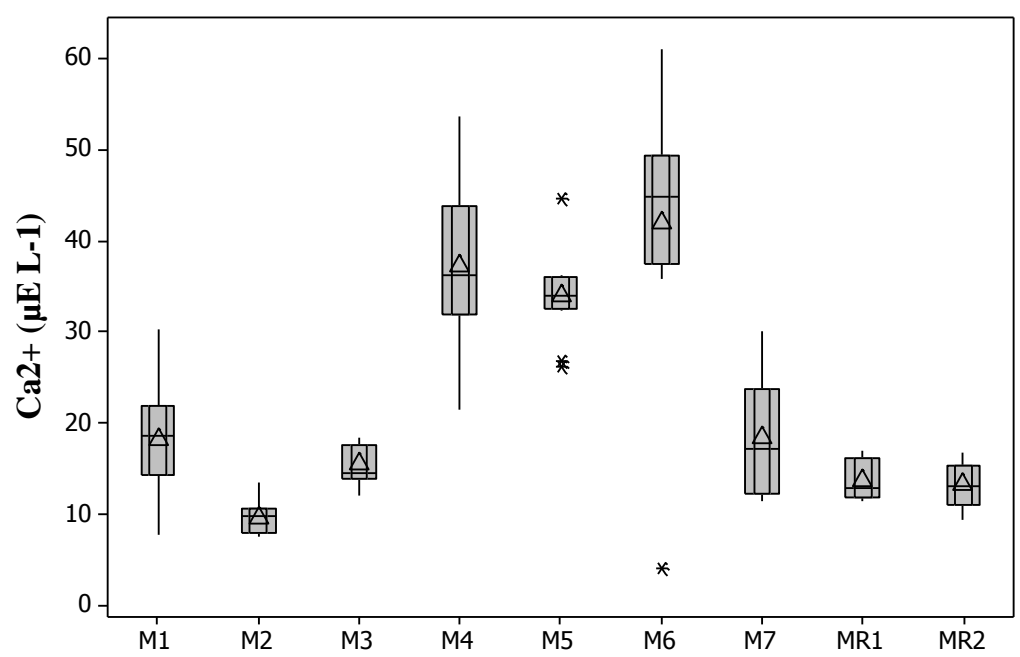

Figure 4. Box plot graph of calcium concentrations along one year period $(n=12)$ in stream water at nine catchments in the Marapanim River Basin, eastern Amazonia.

Source: Barroso (2011).

Fish community studies in the eastern Amazonia have shown that agricultural catchments dominated by small farmer can also support reasonable stream fish diversity. After nine monthly collections, a study identified forty-three fish species in three streams of such agricultural catchments (Corrêa et al., 2012). Later, a more exhaustive collection effort in 
FIGUEIREDO, R. O.; BÖRNER, J.; DAVIDSON, E. A. Watershed services payments to smallholders in the Brazilian Amazon: challenges and perspectives Ambi-Agua, Taubaté, v. 8, n. 2, p. 6-17, 2013. (http://dx.doi.org/10.4136/ambi-agua.1056)

seven streams of the same agriculture region registered seventy-three species distributed in six orders, twenty six families and sixty three genera (Figure 5) (Brejão, 2011).

Moreover, a few of these studies have surveyed sustainable indicators that can be measured in Amazon soils and streams, using rapid field measurements that would allow their use by environmental regulatory agencies. Turbidity, temperature, $\mathrm{pH}$, and dissolved oxygen appear to be the simplest and most indicative parameters for detecting effects of land-use change on water quality in this region (Figueiredo et al., 2010). These measurements could be used as indicators for the payment of watershed services in this region. But further steps are needed, particularly in relation to the values of these environmental services.

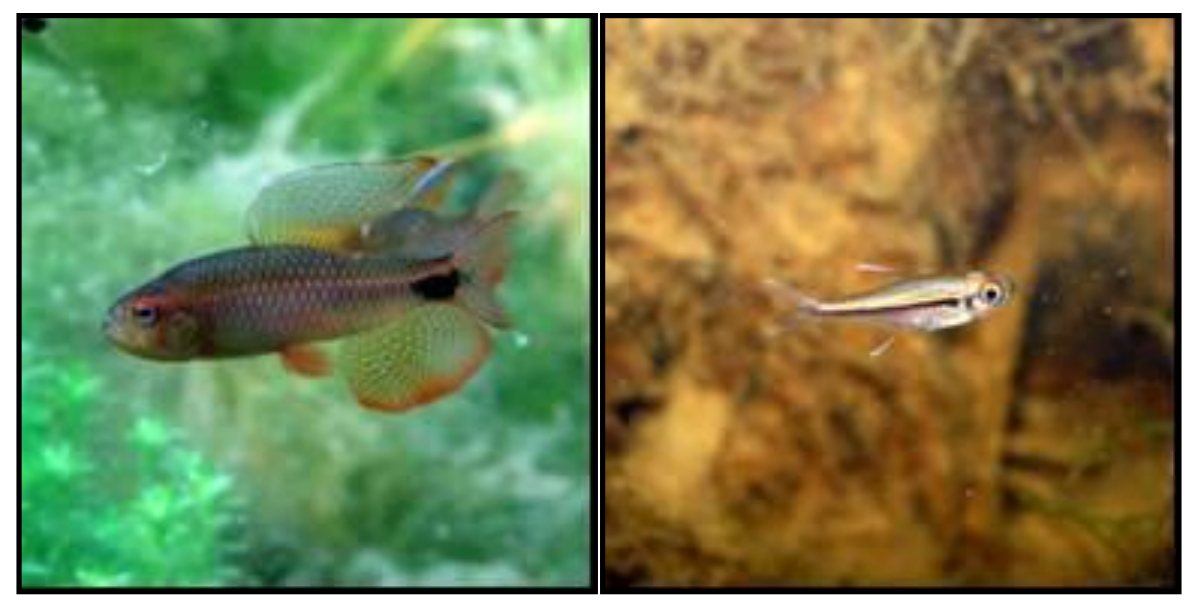

Figure 5. Two of the seventy-three species registered by Brejão (2011) in seven streams of the same agriculture region. From left to right the species in this photos are: Crenuchus spilurus and Hyphessobrycon heterorhabdus.

It can be concluded from the studies shown above and other studies that small landholder agriculture that does not use fire for land management andthat preserves large areas of forest (secondary or mature forests), including riparian zones, can help to mitigate impacts to water quality in small Amazonian streams. This invites study of the possibility of paying for watershed services to small landholders who use conservative agriculture practices in the region, and also possibly compensating large-scale farmers in some way for the same environmental service.

\section{Challenges of setting up payments for Ecosystem Services plans in the Amazon}

As for the hydrobiogeochemical aspects previously discussed, we can infer that, if we want to assure stream water quality in small Amazonian catchments, we need to help producers make the transition from the traditional slash-and-burn agricultural practices that currently prevail in the Amazon frontier toward more diversified and sustainable agricultural and extractive practices. We also need to provide support to producers for adopting watershed conservation measures, such as the restoration of riverbank vegetation. Payments for Environmental Services (PES) have been proposed as effective tools for this purpose (Carvalho et al., 2004). In a watershed study in the Peruvian Amazonian, it was stated that resource management efforts should move quickly to implement programs that reinforce good practices of local people, further educate local people on the ecosystem services provided by riparian areas, and strengthen the institutional framework for maintaining these practices into the future (McClain and Cossío, 2003). 
FIGUEIREDO, R. O.; BÖRNER, J.; DAVIDSON, E. A. Watershed services payments to smallholders in the Brazilian Amazon: challenges and perspectives Ambi-Agua, Taubaté, v. 8, n. 2, p. 6-17, 2013. (http://dx.doi.org/10.4136/ambi-agua.1056)

A fundamental precondition for PES to be feasible is that ecosystem service beneficiaries are willing to pay for at least the costs of setting up and running a given PES scheme. In the case of watershed services, these beneficiaries are typically spatially clustered downstream water users. Many other ecosystem services, such as carbon capture and species habitat provision, result in benefits to society as a whole. In the context of the Amazon, two important challenges arise for PES implementers:

1. Identifying beneficiaries: Low population densities and the relatively flat landscape mean that a critical mass of downstream beneficiaries of such services - a prerequisite for public intervention - is more difficult to identify than in more densely populated mountainous areas.

2. Promoting local collective action: While watershed service providers (farmers) are also to considerable extent service beneficiaries, land disputes and cultural heterogeneities among settlers inhibit local collective efforts to safeguard stream water quality.

With regard to the first challenge, it is crucial to identify a sufficiently large group of service beneficiaries. Experiences from PES efforts around the world show that watershed services can often piggyback in PES plans that address other more globally valued ecosystem services, such as carbon capture and habitat conservation. Mechanisms that link several services are called bundling or layering (Wunder and Wertz-Kanounnikoff, 2009). Economic analyses of conservation opportunity costs of small landholders in the eastern Brazilian Amazon suggest that the costs of setting aside an additional hectare of secondary deforestation lie between roughly $\mathrm{R} \$ 10-20$ per ton of $\mathrm{CO}_{2}$ (Figure 6) (Börner et al., 2007). This is slightly higher than cost-estimates for the retirement of extensive pastures (Bowman et al., 2012; Nepstad et al., 2009; Wunder et al., 2008).

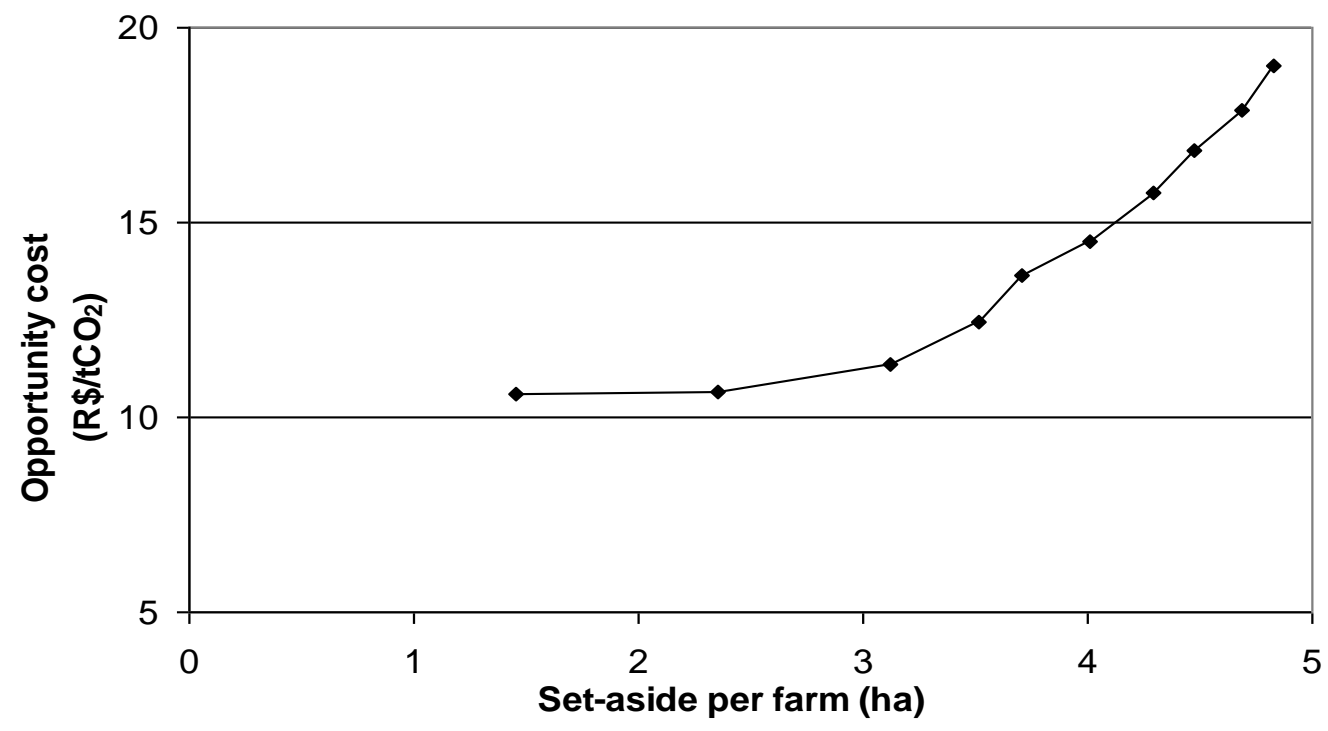

Figure 6. Opportunity costs per unit of avoided $\mathrm{CO}_{2}$ emission in smallholder systems in the eastern Brazilian Amazon.

Source: Modified from Börner et al. (2007).

For many reasons, including transport infrastructure quality and land tenure security, PES schemes may be more competitively established in the eastern Amazon setting than at today's agricultural frontiers, where the costs of implementing local interventions tend to be high. Based on the existing Brazilian Forest Law, carbon payment schemes in the Brazilian 
FIGUEIREDO, R. O.; BÖRNER, J.; DAVIDSON, E. A. Watershed services payments to smallholders in the Brazilian Amazon: challenges and perspectives Ambi-Agua, Taubaté, v. 8, n. 2, p. 6-17, 2013. (http://dx.doi.org/10.4136/ambi-agua.1056)

Amazon could be optimized in terms of watershed service provision, e.g. through higher rewards for the conservation and restoration of riparian vegetation.

With regard to the second challenge, tenure insecurity and the lack of a consistent land register system still represent an important barrier to conservation initiatives in many parts of the Amazon. Collective conservation action is unlikely to come about wherever the social relationship between watershed service providers and service users is dominated by conflicts over land. Efforts to build spatially explicit land registers linked to pragmatic land reform strategies, such as the Cadastro Ambiental Rural (CAR) and the Terra Legal Program, represent promising initiatives in that regard.

\section{OUTLOOK AND CONCLUSIONS}

We have shown that there are: 1. clear differences in water quality indicators between traditionally managed and fire-free managed watersheds; and, 2. clear differences between small landholder versus large-scale producer-managed watersheds.

Watershed services alone, however, are unlikely to evoke sufficient local demand for establishing PES schemes in most Amazonian settings. Optimizing carbon payment schemes, for example, in the context of currently mushrooming REDD+ schemes in the region may represent an opportunity to improve watershed service provision through ecosystem service bundling.

The high degree of dependence of the local population on stream water resources may, nonetheless, also justify public interventions purely based on replacement cost criteria. The potential costs of establishing and maintaining decentralized water treatment facilities as natural watershed services degrade are likely to be higher than investments in promoting improved community watershed management schemes.

\section{ACKNOWLEDGEMENTS}

Authors are grateful to Maria de Cléofas Faggion Alencar for providing bibliographic assistance.

\section{REFERENCES}

BALLESTER, M. V. R.; VICTORIA, D. C.; KRUSCHE, A. V.; COBURN, R.; VICTORIA, R. L.; RICHEY, J. E. A remote sensing/GIS-based physical template to understand the biogeochemistry of the Ji-Paraná river basin (Western Amazônia). Remote Sensing of Environment, n. 87, n. 4, p. 429-445, 2003. http://dx.doi.org/10.1016/j.rse.2002.10.001

BARROSO, D. F. R. Fluxos hidrogeoquímicos em águas fluviais de microbacias do Nordeste paraense e a sua relação com o uso da terra. 121f. 2011. Dissertação (Mestrado em Ciências Ambientais) - Universidade Federal do Pará, Belém, 2011.

BENNETT, G.; CARROLL, N.; HAMILTON, K. Charting new waters: state of watershed payments 2012. Washington, DC: Forest Trends, 2013. Available at: <http://www.ecosystemmarketplace.com/reports/sowp2012>. Access: May 2013.

BIGGS, T. W.; DUNNE, T.; MURAOKA, T. Transport of water, solutes and nutrients from a pasture hillslope, southwestern Brazilian Amazon. Hydrological Processes, v. 20, n. 12, p. 2527-2547, 2006. http://dx.doi.org/10.1002/hyp.6214 
FIGUEIREDO, R. O.; BÖRNER, J.; DAVIDSON, E. A. Watershed services payments to smallholders in the Brazilian Amazon: challenges and perspectives Ambi-Agua, Taubaté, v. 8, n. 2, p. 6-17, 2013. (http://dx.doi.org/10.4136/ambi-agua.1056)

BÖRNER, J.; MENDOZA, A.; VOSTI, S. A. Ecosystem services, agriculture, and rural poverty in the Eastern Brazilian Amazon: interrelationships and policy prescriptions. Ecological Economics, v. 64, n. 2, p. 356-373, 2007. http://dx.doi.org/10.1016 /j.ecolecon.2007.03.001

BOWMAN, M. S.; SOARES-FILHO, B. S.; MERRY, F. D.; NEPSTAD, D. C.; RODRIGUES, H.; ALMEIDA, O. T. Persistence of cattle ranching in the Brazilian Amazon: a spatial analysis of the rationale for beef production. Land Use Policy, v. 29, n. 3, p. 558-568, 2012. http://dx.doi.org/10.1016/j.landusepol.2011.09.009

BREJÃO, G. L. Estradas, alagados antrópicos, peixes e a fragmentação de redes fluviais em uma paisagem agrícola do nordeste do Pará. 94f. 2011. Dissertação (Mestrado em Ciências Ambientais) - Universidade Federal do Pará, Belém, 2011.

CARVAlHO, G.; MOUTINHO, P.; NEPSTAD, D.; MATTOS, L.; SANTILli, M. An Amazon perspective on the forest-climate connection: opportunity for climate mitigation, conservation and development? Environment, Development and Sustainability, v. 6, n. 1/2, p. 163-174, 2004. http://dx.doi.org/10.1023/B:ENVI $.0000003635 .86980 . \mathrm{c} 0$

CORRÊA, J. M.; GERHARD, P.; FIGUEIREDO, R. O. Ictiofauna de igarapés de pequenas bacias de drenagem em área agrícola do Nordeste Paraense, Amazonia Oriental. Revista Ambiente \& Água, v. 7, n. 2, p. 214-230, 2012. http://dx.doi. org/10.4136/ambi-agua.739

DAVIDSON, E. A.; SÁ, T. D. A.; CARVAlHO, C. J. R.; FIGUEIREDO, R. O.; KATO, M. S. A.; KATO, O. R. et al. An integrated greenhouse gas assessment of an alternative to slash-and-burn agriculture in eastern Amazonia. Global Change Biology, v. 14, n. 5, p. 998-1007, 2008. http://dx.doi.org/10.1111/j.1365-2486.2008.01542.x

FEARNSIDE, P. Deforestation in Brazilian Amazonia: history, rates and consequences. Conservation Biology, v. 19, n. 3, p. 680-688, 2005. http://dx.doi.org/10.1111/j.15231739.2005.00697.x

FEARNSIDE, P. Land-tenure issues as factors in environmental destruction in Brazilian Amazonia: the case of southern Pará. World Development, v. 29, n. 8, p. 1361-1372, 2001. http://dx.doi.org/10.1016/S0305-750X(01)00039-0

FIGUEIREDO, R. O.; MARKEWITZ, D.; DAVIDSON, E. A.; SCHULER, A. E.; WATRIN, O. S.; SILVA, P. S. Land-use effects on the chemical attributes of low-order streams in the eastern Amazon. Journal of Geophysical Research: Biogeosciences, v. 115, n. G4, 2010. http://dx.doi.org/10.1029/2009JG001202

FIGUEIREDO, R. O. Processos hidrológicos e biogeoquímicos em bacias hidrográficas sob usos agrícola e agroflorestal na Amazônia Brasileira. In: PORRO, R. (Ed.). Alternativa agroflorestal na Amazônia em transformação. Brasília: Embrapa Informação Tecnológica, 2009. p. 477-500.

MARKEWITZ, D.; DAVIDSON, E. A.; FIGUEIREDO, R. O.; VICTORIA, R. L.; KRUSCHE, A. V. Control of cation concentrations in stream waters by surface soil processes in an Amazonian watershed. Nature, v. 410, p. 802-805, 2001. http://dx.doi.org/10.1038/35071052 
FIGUEIREDO, R. O.; BÖRNER, J.; DAVIDSON, E. A. Watershed services payments to smallholders in the Brazilian Amazon: challenges and perspectives Ambi-Agua, Taubaté, v. 8, n. 2, p. 6-17, 2013. (http://dx.doi.org/10.4136/ambi-agua.1056)

MCCLAIN, M, E.; COSSÍO, R. E. The use of riparian environments in the rural Peruvian Amazon. Environmental Conservation, v. 30, n. 3, p. 242-248, 2003.

MCCLAIN, M. E.; ELSENBEER, H. Terrestrial inputs to Amazon streams and internal biogeochemical processing. In: MCCLAIN, M. E.; VICTORIA. R. L.; RICHEY, J. E. The Biogeochemistry of the Amazon Basin. New York: Oxford University Press, 2001. p. 185-208.

NEILL, C.; DEEGAN, L. A.; THOMAS, S. M.; HAUPERT, C. L.; KRUSCHE, A. V.; BALLESTER, V. M. et al. Deforestation alters the hydraulic and biogeochemical characteristics of small lowland Amazonian streams. Hydrological Processes, v. 20, $\mathrm{n}$. 12, p. 2563-2580, 2006. http://dx.doi.org/10.1002/hyp.6216

NEILL, C.; DEEGAN, L. A.; THOMAS, S. M.; CERRI, C. C. Deforestation for pasture alters nitrogen and phosphorus in small Amazonian streams. Ecological Applications, v. 11, p. 1817-1828, 2001. http://dx.doi.org/10.1890/1051-0761(2001)011[1817:DFPANA] 2.0.CO;2

NEPSTAD, D. C.; SOARES-FILHO, B. S.; MERRY, F. D.; LIMA, A.; MOUTINHO, P. R.; CARTER, J. et al. The end of deforestation in the Brazilian Amazon. Science, v. 326, p. 1350-1351, 2009.

SOMMER R. No Fires! Slash-and-Mulch - A Promising Alternative. ZEFnews, n. 6, p. 8, 2001.

TOMASELLA, J.; NEILL, C.; FIGUEIREDO, R.O.; NOBRE, A. D. Water and chemical budgets at the catchment scale including nutrient Exports From Intact Forests and Disturbed Landscapes. In: KELLER, M.; BUSTAMANTE, M.; GASH, J.; SILVA DIAS, P. Amazonia and global change. Washington: America Geophysical Union, 2009. p. 505-524. (Geophysical Monograph Series, 186).

VIEIRA, I. C. G.; ALMEIDA, A. S.; DAVIDSON, E. A.; STONE, T. A.; CARVALHO, C. J. R.; GUERRERO, J. B. Classifying successional forests using Landsat spectral properties and ecological characteristics in eastern Amazônia. Remote Sensing of Environment, v. 87, n. 4, p. 470-481, 2003. http://dx.doi.org/10.1016/j.rse.2002.09.002

WICKEL, B. Water and nutrient dynamics of a humid tropical watershed in Eastern Amazonia. [S.1.]: University of Bonn, 2004. 120p. (Ecology and Development Series, 21)

WUNDER, S.; WERTZ-KANOUNNIKOFF, S. Payments for ecosystem services: a new way of conserving biodiversity in forests. Journal of Sustainable Forestry, v. 28, n. 3/5, p. 576-596, 2009. http://dx.doi.org/10.1080/10549810902905669

WUNDER, S.; BÖRNER, J.; RÜGNITZ, M. T.; PEREIRA, L. Pagamentos por serviços ambientais: perspectivas para a Amazônia. Brasília: Ministério do Meio Ambiente, 2008. 